\title{
IMPLEMENTASI PROMOSI BAURAN KOMUNIKASI PEMASARAN KARTU KREDIT DI INDONESIA (Studi Deskriptif Bank Mandiri, HSBC, Citibank, BCA dan BNI)
}

\author{
Ilham Prisgunanto \\ Komunikasi Sosial, Sekolah Tinggi Ilmu Kepolisian - Perguruan Tinggi Ilmu Kepolisian \\ Email ; prisgunanto@gmail.com
}

\begin{abstract}
Credit cards are one of the most familiar payment tools for information society. They used integrated marketing communications method to get new costumers. They prepared this method to market expansion. Intergrated marketing communication depend on understanding of company about marketing of communication. This research aims to explore implementation of used integrated marketing communications. This research used theory of marketing communication, theory of integrated marketing communications, promotion and marketing plan. This reaearch method is qualitative descriptive. They collected data from staff and management of bank who produce credit card used interview method (Mandiri, HSBC, BCA, Citibank dan BNI). The result is Local Banks which produce credit card did same promotion method with the International bank method. The big issue about credit card is They must used international big brand from Citibank to arrange their system. The Marketing communication is success because of pattern of organization, cross sectoral integration in corporate. Because of that situation, its important to marketing communication at banking.
\end{abstract}

Keywords: promotion, marketing communication, credit card, banking, marketing mix

\section{PENDAHULUAN}

Dunia sudah memasuki era digital yang ditandai dengan perubahan konstelasi interaksi perdagangan yang semua menggunakan uang sebagai alat pembayaran bergeser kepada uang elektronik yang marak digunakan saat ini. Sebelumnya teknologi kartu kredit ikut membentuk pola perdagangan yang dilakukan antar manusia dengan manusia. Diakui bahwa penggunaan kartu kredit di masyarakat makin ekstensif sesuai hasil laporan Industri di Indonesia (BKPM, 2008) ada tiga faktor pemicu, yakni; reduksi tarif bunga kredit, program diskon dalam penjualan item-item tertentu, peningkatan limit kredit terprogram dan program reward point yang menarik nasabah. Maraknya jasa dan promosi yang diberikan pihak penyelenggara kartu mempengaruhi perluasan pasar dan tiap bank dituntut memperluas peluang ini untuk menarik nasabah.

Satu yang diakui, bahwa penggunaan kartu kredit tidak hanya didasarkan kepada kebutuhan melainkan lebih kepada gengsi dan gaya hidup untuk sebagian masyarakat. Kemudahan dalam penggunaan dan bunga kredit yang kecil menambah keinginan untuk menggunakan kartu kredit sebagai alat pembayaran dalam perdagangan. Di samping murah, unsur keamanan dan kepercayaan pihak bank menjadi pertimbangan kuat orang 
menggunakan kartu kredit. Keamanan dilihat dari tidak efektifnya orang membawa uang kontan yang rawan dengan perampokan dan penodongan dari sisi kriminalitas, kepercayaan pihak bank karena penggunaan aliran dana yang jelas menambah kuat animo orang untuk menggunakan kartu kredit.

Kebiasaan masyarakat dalam menggunakan kartu kredit dalam keperluan perdagangan tidak lepas dari teknik promosi yang dilakukan oleh penyelenggara kartu kredit tersebut. Pola sosialisasi dan promosi akan sangat kentara tertuju atau tidak dilihat dari implementasi dari penggunaan bauran promosi komunikasi pemasaran yang dipakai oleh perusahaan atau institusi tersebut. Keseriusan dari penyelenggara kartu kredit dalam membentuk kesadaran masyarakat pengguna uang elektronik di era digital.

Dengan adanya teknologi terbaru, maka masalah keamanan akan keuangan dan informasi diri menjadi hal yang sangat penting bagi pengguna kartu kredit. Penggunaan 3DS atau 3 Domain Secure adalah perlindungan kartu kredit dimana yang bertanggung jawab adalah 3 pihak, yaitu acquiring bank (Bank yang mengambil uang), Issuing Bank (Bank yang menerbitkan kartu kredit) dan Payment Gateway \& Merchant (Sistem yang memproses transaksi).

Perbedaan mencolok dari 3DS dibandingkan proses transaksi kartu kredit konvensional adalah adanya satu tahapan ekstra. Dimana setelah mengirimkan informasi kartu kredit, pengguna akan diminta untuk memasukkan OTP (One Time Pin) berupa nomer PIN acak yang dikirimkan ke nomer ponsel pelanggan. Dengan model seperti ini, maka akan menyelesaikan masalah card not present (CNP). Ketika pelanggan bertransaksi menggunakan kartu kredit secara fisik, maka pelanggan harus menyerahkan kartu kredit itu untuk digesek. Dari sini maka peluang fraud menjadi sangat kecil karena kartu secara fisik harus ada (id.techinasia.com).

Ketakutan masyarakat Indonesia dalam penggunaan kartu kredit memang tidak beralasan, terutama berkaitan dengan kemungkinan kebocoran pada data informasi pribadi penggunanya. Padahal pelaku industri kartu kredit mengakui, bahwa Indonesia memiliki potensi sangat besar dalam penggunaan kartu kredit. Saat ini dengan jumlah penduduk 250 juta jiwa, penggunaan kartu kredit baru mencapai 17 juta jiwa atau kurang dari 10 persen. Indonesia sebagai negara yang ekonominya sedang berkembang dan maju, maka penggunaan kartu kredit begitu besar. Masyarakat yang aktif bertransaksi daring, maka tingkat kebutuhan menggunakn kartu kredit juga dapat dipastikan besar. Transaksi daring sudah dipastikan meningkat dengan marak penggunaan aplikasi berbasis internet melalui telepon cerdas seiring meningkatnya jumlah penggunaan telepon cerdas saat ini. Dengan penggunaan jejaring 
internet maka pemegang kartu kredit dapat dengan mudah memeriksa riwayat transaksi dan tagihan mereka (Pikiran-Rakyat.com)

Guna menggalakkan penggunaan kartu kredit, diperlukan promosi program yang serius oleh bank penyelenggara kartu kredit. Salah satu yang perlu dilakukan bank adalah dengan merancang bauran promosi dalam komunikasi pemasaran yang efektif. Keseriusan hal ini akan menunjukkan itikad dan sikap baik bank penyelenggara kartu kredit di mata konsumen.

Dari pemaparan di atas, maka permasalahan penelitian adalah ;

1. Bagaimana promosi bauran pemasaran yang dilakukan oleh para bank penyelenggara kartu kredit, dan pihak mana yang dianggap paling kuat mengarahkan dan menjual produk ke nasabah?

2. Bagaimana pandangan pelaku industri kartu kredit terhadap penerapan promosi melalui sarana komunikasi pemasaran yang dilakukan?

\section{KAJIAN PUSTAKA}

Dunia perbankan sudah merambah ke semua sektor mulai dari pengelolaan uang, asuransi bahkan ada yang ke bisnis properti sampai perluasan pasar yang paling mendesak adalah penyelenggara kartu kredit agar mereka tetap bertahan hidup dalam upaya mendapat nasabah baru. Tidak mudah mendapatkan nasabah baru perlu adanya pendekatan khusus dan penciptaan brand yang kuat yang menempel erat pada organisasi. Duncan (2002: 11-15) menyatakan:

"to understand IMC, you must have a basic understanding of marketing, because IMC functions under marketing umbrella. This discussion explains products, market, brands, the exchange, the marketing process, the marketing concept, competitive advantage and the marketing mix."

Jelas, bahwa komunikasi pemasaran mempunyai komponen pokok; produk, pasar, merek, pertukaran, proses, konsep pemasaran, keunggulan kompetitif dan bauran pemasaran. Di sini pemasaran selalu berdampingan dengan usaha mengkomunikasikan produk atau jasa kepada konsumen (Sulaksana, 2003: 1-9). Proses ini disebut proses komunikasi pemasaran dalam upaya perluasan dan pendalaman kualitas pasar dengan komunikasi pemasaran (Kertajaya, 2005: 7-17).

Dalam rumusan pemasaran modern, ada dua hal penting yang ditekankan menurut Drucker, yaitu pemasaran itu sendiri dan inovasi. Konsep pemasaran yang berkembang adalah konsep pemasaran inovatif atau kemampuan untuk selalu berubah terus menerus untuk mencapai tujuan (Drucker, 1999). Memang, ada dua wacana lanjutan, apakah pasar mengendalikan perusahaan, atau perusahaan yang mendidik pasar? Inilah inti wacana pemasaran modern market driver menjadi market driving. Komunikasi pemasaran modern tidak luput dalam wacana pasar, yakni; market driver marketing 
communication atau market driving marketing communication?

Peran dan fungsi komunikasi pemasaran menjadi penting dalam perluasan, mempertahankan dan mendidik konsumen (nasabah). Dalam perspektif ini terjadi pergeseran dari driver menjadi driving yang melibatkan inti komponen pemasaran, yaitu; value. Park dan Lessig (1977) pernah menyatakan, "The individual feels that the purchase or use of a particular brand possess the characteristics that she or he would like to have". Istilah value sendiri mengandung arti luas, Kotler (2005) menyebutnya estimasi konsumen terhadap product overall capacity. Rumusan utama marketing mix tidak boleh menjadi rumusan stagnan dan perlu inovasi yang sesuai pasar. Posisi place, product, price dan promotion harus menyesuaikan diri dengan posisi jasa perbankan dan perkembangan teknologi komunikasi modern (Kertajaya, 2005:10-20).

Pada kenyataannya, bauran pemasaran modern berhadapan dengan perubahan atau revolusi dramatis pola dan sikap transaksi ekonomi modern. Dalam perkembangannya perdebatan marketing mix tidak hanya bicara tentang $4 \mathrm{P}$ saja tapi juga sampai $5 \mathrm{P}$ atau $7 \mathrm{P}$. Smith (2004:6-10) menyatakan bahwa

The marketing mix is essentially a concetual framework tha helps to structure the approach to each marketing challenge. There many different approaches to the marketing mix eg. 4P's, 5P's or 7P's. 4P's nevertheless do provide a basic framework. Thse for ingredients can be mixed together in an infinite numberof ways. Some argue that the most important $P$ - people - is missing. The additional process like physical evidence and process can be added ini this whole process.

Perdebatan ini berlanjut pada masalah kedudukan, peran dan fungsi komunikasi pemasaran. Pola baru era pemasaran modern menganggap konsumen sebagai pihak penting, sedangkan profit adalah konsekuensi logis sebuah proses pemasaran. Market driving marketing communication mencatat posisi baru peran komunikasi pemasaran untuk mendidik nasabah menjadi pelaku baru perbankan modern (Sulaksana. 2005: 2-4). Turbulensi kondisi dan pola sikap konsumen perbankan memunculkan anggapan bahwa komunikasi pemasaran klasik tidak lagi memadai menjawab tantangan pemasaran modern. Tidak mengherankan bila faktor komunikasi pemasaran terpadu menjadi pilihan alternatif dalam pengembangan komunikasi pemasaran.

Di samping itu juga penerapan dari komunikasi pemasaran adalah adanya bauran komunikasi pemasaran (Marketing communication mix), yang berfungsi peningkatan efektifitas dan efisiensi dalam komunikasi pemasaran dari delapan model komunikasi utama (Kotler \& Keller, 2009), antara lain : 
1. Iklan, yaitu semua bentuk terbayar dari presentasi non personal dan promosi ide, barang atau jasa melalui sponsor yang jelas.

2. Promosi penjualan, berbagai insentif jangka pendek untuk mendorong aplikasi atau pembelian produk atau jasa.

3. Acara dan pengalaman, kegiatan dan program yang diseponsori perusahaan yang dirancang untuk menciptakan interaksi harian atau interaksi yang berhubungan dengan merek tertentu.

4. Hubungan masyarakat dan publisitas, beragam program yang dirancang untuk mempromosikan atau melindungi citra perusahaan atau produk individunya.

5. Pemasaran langsung,penggunaan surat, telepon, faksimile, e-mail, atau internet untuk berkomunikasi secara langsung dengan atau memintan respons atau dialog dari pelanggan dan prospek tertentu.

6. Pemasaran interaktif, kegiatan dan program online yang dirancang untuk melibatkan pelanggan atau prospek secara langsung atau tidak langsung meningkatkan kesadaran, memperbaiki citra, atau menciptakan penjualan produk dan jasa.

7. Pemasaran dari mulut ke mulut, komuni kasi lisan, tertulis, dan elektronik antar masyarakat yang berhubungan dengan keunggulan atau pengalaman membeli atau menggunakan produk atau jasa.

8. Penjualan personel, interaksi tatap muka dengan satu atau lebih pembeli prospektif untuk tujuan melakukan presentasi, menjawab pertayaan, dan pengadaan pesanan.

Kerangka dasar komunikasi pemasaran oleh perusahaan dapat dirahkan untuk mempengaruhi konsumen terhadap gaya, dan harga produk, bentuk dan warna kemasan, sikap dan cara berpakaian wiraniaga, dekorasi toko, sebagai bentuk komunikasi kepada pembeli. Kotler \& Keller (2009), menggambarkan unsur-unsur dalam kerangka dasar komunikasi umum sebagai alat komunikasi antara pemasar dengan pembeli.

\section{METODOLOGI PENELITIAN}

Penelitian ini menggunakan perspektif interpretatif (subjektif) yang berusaha memberikan makna atas interaksi antara subyek dengan obyek penelitian. Informasi yang di dapat bukan sekedar hasil dari proses komunikasi, melainkan lebih pada cara berpikir. Penelitian ini berdasarkan analisis teori-teori, prinsip-prinsip serta asumsi-asumsi dasar ilmu pengetahuan dengan menggunakan penalaran deduktif-deduktif serta prosedur teknik sistematik. Penelitian dilakukan secara ilmiah dengan menggunakan metode dan teknik tertentu dengan permasalahan yang dihadapi. Dalam suatu penelitian ilmiah diperlukan suatu metode penelitian yang 
sesuai dengan pokok permasalahan yang akan diteliti.

Metode penelitian yang digunakan adalah analisis deskriptif dengan pendekatan kualitatif. Bogdan dan Taylor dalam mendefinisikan metodologi penelitian kualitatif sebagai prosedur penelitian yang menghasilkan data deskriptif berupa kata-kata tertulis atau lisan dari orang-orang dan perilaku yang dapat diamati. Menurut Loftand dan Lofland dalam buku Moleong sumber data utama dalam penelitian kualitatif ialah kata-kata dan tindakan, selebihnya adalah tambahan, seperti: dokumen dan lain-lain (Moleong, 2004:157).

Penelitian kualitatif adalah penelitian yang bermaksud untuk memahami fenomena tentang apa yang dialami oleh subyek penelitian, misalnya; perilaku, persepsi, motivasi, tindakan, dan lain-lain. Penelitian kualitatif adalah penelitian yang tidak mengandalkan bukti berdasarkan logika, sistematis, prinsip angka atau metode statistik. Pembicaraan sebenarnya, isyarat dan tindakan sosial lainnya adalah bahan mentah untuk analisis kualitatif (Mulyana, 2004:150). Penelitian kualitatif merupakan penelitian yang menggunakan latar ilmiah, dengan maksud menafsirkan fenomena yang terjadi dan dilakukan dengan jalan melibatkan berbagai metode yang ada. Dengan berbagai karakteristik khas yang dimiliki, penelitian kualitatif memiliki keunikan tersendiri sehingga berbeda dengan penelitian kuantitatif.

Metode pengumpulan data dengan teknik atau cara-cara kualitatif bersumber pada wawancara dan pengamatan terlibat. Dalam ilmu komunikasi segala macam tanda merupakan teks yang di dalamnya terdapat simbol-simbol yang sengaja dipilih, dimana pemilihan, penyusunannya dan penyampaiannya tidak bebas dari maksud tertentu. Oleh sebab itu akan memunculkan makna tertentu.

Data primer adalah wawancara langsung dengan pelaku industri kartu kredit. Data sekunder adalah data yang diperoleh secara tidak langsung melalui pengamatan langsung. Data sekunder berbentuk catatan atau laporan yang terdokumentasi. Teknik pengumpulan data yang dilakukan dalam data sekunder adalah melalui studi kepustakaan. Studi kepustakaan, dalam sebuah penelitian mengacu kepada teori-teori yang berlaku dan dapat dicari pada buku-buku teks ataupun dari hasil penelitan orang lain baik yang tidak dipublikasikan maupun belum dan merupakan satu faktor dari keilmiahan peneliti yang akan dilakukan.

Metode analisis data yang digunakan dalam penelitian ini adalah analisis deskriptif pendekatan kualitatif. Wawancara dilakukan kepada (narasumber 1) Senior vice President Kartu Kredit Bank Mandiri, (narasumber 2) Vice President Credit card Bank HSBC, 
(narasumber 3) Vice President Credit card Bank BCA, (narasumber 4) Vice President Credit Card Citibank dan (narasumber 5) General Manager Customer Banking BNI

\section{HASIL DAN PEMBAHASAN}

Bank-bank penyelenggara kartu kredit terkemuka sudah berdiri hampir di atas lima puluhan tahunan dan memiliki nasabah besar. Komposisi yang ada, yakni; Citibank, BCA dan HSBC adalah bank-bank asing yang sudah lama beroperasi dan berkutat di dunia perbankan dan bisnis di Indonesia. Berbeda dengan itu bank BNI dan bank Mandiri merupakan bank-bank Pemerintah atau Negara yang ada karena dukungan penjaminan Negara yang kuat. Dapat juga dikatakan kredibilitas dan loyalitas kepada nasabah tinggi. Dengan demikian dapat dikatakan pilihan bank dalam penelitian ini tepat, mengingat IMC dipentingkan adalah penciptaan brand atau merek citra perusahaan.

Komposisi seimbang ini akan memberikan nuansa dan temuan-temuan menarik terhadap strategi dan model komunikasi pemasaran yang dilakukan dalam memberikan pelayanan kartu kredit kepada nasabah. Penelitian ini akan membongkar bahasan penting mengupas permasalahan strategi dan taktik komunikasi pemasaran terintegrasi perbankan di Indonesia dalam keperluan membangun brand. Bank asing dianggap lebih inovatif dan penuh dengan pembaruan dalam operasionalisasinya. Bank- bank yang diteliti memiliki brand kuat dalam masyarakat. Kekuatan brand ini akan mengacu pada strategi dan taktik dalam keperluan menjaga segmentasi pasar mereka. Kesesuaian akan masalah brand dikaitkan dengan keandalan komunikasi adalah fokus masalah yang hendak dicapai. Dengan demikian dapat diakui bahwa kelima bank ini memiliki kemampuan mengubah sikap dan perilaku masyarakat dalam bertransaksi bisnis dalam kehidupan.

\section{Strategi Dalam Komunikasi Pemasaran}

Komunikasi pemasaran adalah bagian dari marketing mix yang berfungsi untuk mengkomunikasikan bagian-bagian yang signifikan dari berbagai elemen pemasaran lainnya, seperti; produk, harga, promosi dan distribusi guna meningkatkan pembelian (Burnett and Moriarty, 1998: 4). Strategi komunikasi pemasaran menggambarkan pesan yang akan berbagi dengan target pelanggan (audiens) khusus melalui komunikasi pemasaran (Prisgunanto, 2006: 88).

Strategi dalam komunikasi pemasaran secara lugas dapat dibagi menjadi dua bagian, yakni; push strategy dan pull strategy (Ibid, 2006: 90). Dalam push strategy lebih mengimplementasikan tentang promosi langsung yang dilakukan oleh perusahaan atau istilah yang kerap digunakan adalah below the line. Sebaliknya dalam pull strategy untuk komunikasi pemasaran lebih menggunakan media massa dalam menarik ketertarikan 
pelanggan kepada sebuah produk. Istilah yang banyak digunakan juga dalam masalah pull strategy ini adalah above the line. Keduanya akan terlihat dari penggunaan sarana-sarana komunikasi pemasaran yang ada.

\section{Advertising (Iklan)}

"Kami memilih media cetak nasional, seperti Kompas, Radio juga. Namun dari semua kami mengandalkan sosialisasi below the line" saat ini. Dahulu pernah ada acara program televisi, tetapi saat ini tidak diteruskan karena sepertinya agak melenceng dari tujuan semula," (narasumber 1)

"Kami memilih print media untuk advertising khusus di majalah-majalah di 15 kota terbesar di Indonesia dan radio lokal. Kami banyak menggunakan mediamedia cetak lokal, karena memang kami berkompetisi dengan BCA yang bermain juga pada segmentasi yang sama," (narasumber 5)

"Citibank lebih menggunakan iklan di media cetak nasional yang terkemuka, seperti Kompas, Koran Tempo, dan majalah-majalah ekslusif. Jelas kami lakukan itu karena calon pelanggan kami adalah orang-orang yang sudah sangat mapan. Dahulu kami promosi iklan melalui spot acara TV "Broad Living the Plasa" tapi dihentikan. Sampai sekarang tidak ada acara program khusus (narasumber 4).

Dari iklan dapat diketahui bahwa calon pelanggan dan penggunaan kartu kredit terwakili dari sarana ini. Penggunaan media massa akan memberikan karakteristik secara aspek sosiologis dari calon pelanggan. Citibank dan bank HSBC mempromosikan iklan melalui media cetak nasional sangat cocok bagi kalangan yang sudah mapan dan memiliki penghasilan yang tinggi. Berbeda dengan itu bank BCA, BNI dan Mandiri saat ini lebih menggunakan media massa cetak yang lokal karena memang target pelanggan mereka adalah pelanggan lokal yang ada di tiap-tiap daerah sesuai karakteristik kewilayahan yang dimiliki.

Periklanan merupakan cara menjual melalui penyebaran informasi. Tentu saja informasi yang diberikan tidak sembarangan dan tidak semua informasi adalah iklan. Artinya di dalam iklan biasanya berisi tentang perang informasi yang berusaha untuk mempengaruhi sikap beli dan pengarahan pada perilaku konsumen. Tentu saja dalam hal ini konsumen dikuasai dalam alam maya dan jangkauan komunikasi yang dimiliki. Periklanan harus dapat mempengaruhi pemilihan dan keputusan membeli konsumen. Periklanan selalu berisi bujukan kepada khalayak secara massif agar berperilaku sesuai dengan strategi pemasaran perusahaan untuk mencetak penjualan dan keuntungan.

Esensi periklanan yang tidak disebutkan menjadi permasalahan apakah bank penyelenggara kartu kredit sudah memahami peran dan fungsi iklan. Kebanyakan bank penyelenggara kartu kredit kurang antusias bila berbicara tentang periklanan. Bank-bank penyelenggara kartu kredit sering membuat iklan produk dikaitkan dalam konten (isi), cenderung sama satu dengan yang lainnya. 
Pola keseragaman ini menyebabkan konsumen cukup sulit untuk melakukan pemilihan dan keputusan untuk menjadi pelanggan salah satu kartu kredit. Jasa dan Layanan yang sama dan seragam antara satu dengan yang lain menunjukkan adanya pola meniru antara satu dengan yang lain.

Tidak ada keunikan yang diberikan dalam kartu kredit yang menjadi karakteristik dari jenis kartu tersebut. Iklan yang sangat kentara berbeda sedikit ada dalam kartu kredit yang dikeluarkan oleh bank Pemerintah. Kebanyakan bank Pemerintah memberikan layanan yang lokal dengan keutamaan pada pelanggan dalam negeri. Konsep lokal yang ditawarkan termasuk dalam jasa dan layanan yang diberikan. Namun sayangnya, banyak bank dalam negeri penyelenggara kartu kredit kerap ikut memberikan layanan yang bersifat internasional dan global karena menganggap sedemikianlah kegunaan dan keutamaan dari kartu kredit.

Padahal tindakan tersebut akan menghilangkan keutamaan dan kekhasan yang dimiliki oleh kartu kredit dari yang diberikan bank tersebut. Padahal seperti yang diketahui, bank leader dalam kartu kredit malah sedang mengembangkan dan memperluas sayap bisnisnya kepada bentuk iklan yang menjelaskan informasi bahwa produk-produk kartu kredit guna mencapai pada kelokalan yang ada. Tentu saja upaya memperoleh pasar lokal menjadi target penting dalam merebut pasar baru bagi bank-bank asing internasional. Nilai inilah di dalam iklan yang seharusnya diutamakan dan dilancarkan oleh bank-bank dalam negeri.

Dalam menyambut AFTA (pasar bebas) ke depan, akan diketahui bahwa akan ada pasar terbuka dan pemberian kebebasan kepada semua pihak untuk melakukan transaksi tanpa ada dominasi dan ikut campur kekuasaan Negara-Negara. Dengan tidak adanya proteksi Negara menyebabkan pelaku pasar bebas melakukan penetrasi dan merebut pasar-pasar lokal dengan keleluasaan yang absolut. Dalam artian siapa yang lemah akan kalah dan tergusur. Demikianlah hukum pasar yang akan dialami oleh pelaku bisnis di Indonesia. Bank-bank asing akan masuk ke dalam pasar di Indonesia dengan jasa dan layanan yang disebutkan dalam informasi iklan.

Dominasi iklan-iklan kartu kredit bank internasional yang lebih menguasai dunia periklanan sudah menunjukkan bahwa semua isu-isu dan tema dalam periklanan dalam kartu kredit sudah dikuasai oleh bank-bank asing internasional. Bank-bank lokal dan Pemerintah kebanyakan hanya mengikuti dan mengekor dengan mengubah pada isu-su kelokalan. Tentu saja isi informasi iklan sedemikian akan membingungkan calon pelanggan dalam menentukan pilihan terhadap produk kartu kredit. Sebaliknya bermain iklan dalam konten-konten isu tentang jasa dan layanan 
yang global seperti dilangsir oleh bank-bank asing akan berimbas kepada hilangnya keunikan kelokalan yang dimiliki bank dalam negeri. Konteks inilah yang perlu diperhatikan dalam memproteksi bank-bank dalam negeri terhadap serangan kartu kredit bank-bank asing.

\section{Direct marketing}

"Kartu kredit ada edisi dan list-list-nya dan semua dilakukan juga dalam penjualan langsung. Kegiatan PR sangat sedikit sekali memberikan masukkan pemasaran, tetapi ada," (narasumber 5)

"Kalau kami direct marketing bukan penjualan kartu kreditnya melainkan potongan-potongan harga dan keistimewaan dalam menggunakan kartu kredit (narasumber 3 )

Sarana direct marketing lebih mengutamakan penjualan langsung yang dilakukan oleh pihak bank. Dari sana dapat diketahui pola penjualan yang diberikan. Pada bank BNI direct marketing sangat diberdayakan dalam menjaring pelanggan sebanyak-banyaknya. Berbeda dengan itu bank BCA malah melakukan direct marketing terhadap layanan dan kelebihan-kelebihan kartu. Misalnya ada potongan harga, produk gratis dan hal-hal istimewa lain dalam layanan kepada pelanggan. Diakui bahwa banyak pelanggan kartu kredit yang tidak tahu tentang informasi keutamaan kartu kredit mereka. Direct marketing tersebut bertujuan untuk mengoptimalkan penggunaan kartu kredit yang dimiliki. Sebab semakin kartu kredit digunakan semakin memberikan keuntungan kepada pihak bank. Direct marketing dapat diartikan dengan hubungan langsung antara marketing dengan konsumen dengan mengharapkan tanggapan dan hubungan yang cepat dan tepat di antara keduabelah pihak.

Dalam kasus Direct Marketing kartu kredit dapat diketahui bank penyelenggara tidak memahami direct marketing sebagai sarana handal yang digunakan untuk melakukan penjualan. Seperti yang diketahui bahwa masyarakat asia termasuk Indonesia sangat dipengaruhi oleh model komunikasi ini. Pengutamaan pada keintiman dan pola komunikasi langsung merupakan ciri dari masyarakat paternalistik yang menganut budaya kolektivistik (Mulyana dan Rakhmat : 2003). Masyarakat yang berciri pada model kolektivistik cemderung kurang menggunakan media massa dalam pola berkomunikasi yang digunakan. Kebanyakan mereka lebih mengandalkan komunikasi antar pribadi yang bersifat oral atau langsung antar manusia. Dengan demikian unsur non verbal akan lebih memiliki arti yang lebih mendalam dari pada unsur tulisan. Praktik Komunikasi pemasaran model seperti ini hanya dijawab dan ditanggapi oleh dua bank, sepertinya kurang antusias pihak bank penyelenggara kartu kredit menjawab pola promosi dan pengenalan ini daripada sarana komunikasi pemasaran yang lain. 
Pola-pola penggunaan media massa oleh bank-bank penyelenggara kartu kredit menunjukkan tren yang sangat mengikuti model yang digunakan oleh bank leader yang berada di luar negeri dengan konteks peradaban asing dan barat. Keutamaan kelokalan dengan pola direct selling sering dilupakan dan tergilas dalam promosi dan perang informasi melalui dunia periklanan. Padahal unsur utama keintiman dalam komunikasi pemasaran untuk keperluan promosi lebih mengena pada pemikiran orang asia, termasuk Indonesia. Penguasaan keintiman yang dapat didominasi oleh bankbank lokal dalam direct marketing dapat dijadikan sebagai senjata dan perlindungan terhadap pasar lokal.

\section{Below The Line}

"Bank kami saat ini sangat mengandalkan promosi pendekatan langsung melalui below the line, seperti promosi melalui pameran, dan louching-louching produk". (narasumber 1)

"Saat ini bank BNI berusaha mendekati calon pelanggan secara langsung. Caranya dengan mempromosikan pada kegiatankegiatan di masyarakat dan kampuskampus. Pendanaan kegiatan-kegiatan seperti ini sering kami lakukan dalam upaya untuk mendekatkan diri dengan pelanggan" (narasumber 5)

Promosi melalui below the line merupakan bagian dari praktik komunikasi pemasaran diketahui sangat menggunakan prinsip komunikasi antar pribadi yang ada. Pola komunikasi antar pribadi ini menggunakan keintiman dengan melibatkan langsung dan masuk ke dalam lingkungan yang dituju. Dalam hal ini yang dituju adalah pelanggan, tentu saja bank harus secara aktif memberikan atensi guna mendapatkan kepercayaan pelanggan sepenuhnya. Bankbank penyelenggara kartu kredit berpendapat, bahwa komunikasi pemasaran below the line adalah semua sarana komunikasi yang berhubungan dengan keintiman dan kedekatan dalam ikatan antar pribadi yang sesungguhnya.

Promosi melalui below the line dalam pemahaman ini sebenarnya masuk dalam dua model komunikasi pemasaran yang ada, yakni penjualan pribadi dan hubungan masyarakat (public relations). Banyak orang menganggap penjualan pribadi dianggap bukan penjualan yang sesungguhnya. Hal ini disebabkan begitu kentalnya sarana komunikasi pemasaran ini dengan unsur keintiman yang ada. Terkadang orang tidak bisa membedakan antara penjualan dengan hubungan antar pribadi yang dikaitkan dengan pola hubungan komunikasi. Pemahaman yang menyamakan antara kedua fungsi sarana komunikasi pemasaran ini akan menyulitkan dalam kategorisasi dan

Komunikasi pemasaran melalui hubungan masyarakat (public relations) kerap diartikan sama dan tersamarkan dengan fungsi Periklanan. Hubungan masyarakat (public relations) seharusnya didekatkan pada pemahaman publisitas yang dilakukan oleh pihak perusahaan yang dalam hal ini adalah bank. Humas (public relations) berusaha 
mendidik dan memberikan pemahaman pengetahuan yang sesungguhnya bagi masyarakat. Sasaran utamanya adalah mendidik pasar dengan informasi aktual sesuai kenyataan yang bisa dipercaya secara imparsial dan tidak memihak. Dengan demikian jelas Humas (public relations) sangat berbeda dengan periklanan yang memiliki tedensi terhadap isi pesan yang hanya melulu bertujuan utama pada pengarahan sikap beli.

Humas (public relations) tidak memprovokasi dan memberikan informasi berlebihan dengan nada berlebih-lebihan, malah sebaliknya memberikan informasi yang sesungguhnya dan relevan dengan kondisi saat ini. Keterangan informasi yang diberikan Humas lebih berupaya menyadarkan masyarakat dari sisi positif yang ada tentang sebuah produk. Berbeda dengan periklanan yang memang bertujuan mengupayakan secara dramatis guna menyentuh aspek emosional konsumen terhadap produk dan layanan yang ada. Iklan memang berupaya mengarahkan dan mempengaruhi perilaku dan sikap orang terhadap produk.

Diharapkan dari iklan konsumen akan terpengaruh dan berperilaku sesuai apa yang ada dalam isi (konten) iklan tersebut. Oleh sebab itu informasi dalam periklanan penuh dengan bias. Berbeda dengan Humas (public relations) yang lebih berisi informasi mendidik dan yang sesungguhnya ke masyarakat. Pola komunikasi pemasaran melalui below the line ini lebih marak dan kerap dilakukan oleh bank-bank Pemerintah, daripada bank swasta nasional atau internasional. Penerapan sedemikian sangat tepat, karena untuk mengubah pandangan dan sikap pelanggan yang 'miring' terhadap bank Pemerintah. Di samping itu juga memang bank Pemerintah baru bermain dalam bisnis kartu kredit ini. Dapat dikatakan praktik komunikasi pemasaran yang dilakukan oleh bank-bank penyelenggara kartu kredit sudah sesuai dengan yang ada. Bank-bank penyelenggara kartu kredit sudah terbagi dalam dua kubu, yaitu bank-bank Pemerintah dengan isu-isu kelokalannya dengan bank-bank swasta asing yang mengutamakan layanan jaringan global.

Sayangnya dari semua bank yang menyatakan melakukan below the line kebanyakan mereka tidak menekankan pada pentingnya public relations dibandingkan dengan penjualan pribadi (personal selling). Diketahui bahwa komunikasi pemasaran dalam hal ini disamadiartikan dengan penjualan saja tidak lebih. Tidak ada upaya menyadarkan dan memberikan pendidikan terhadap pola perilaku konsumen dalam menggunakan kartu kredit secara mendalam. Penciptaan konsumen yang bijak dalam menggunakan kartu kredit dalam memasuki kecenderungan tren electronic society adalah hal utama yang hendaknya dilangsir oleh humas (public relations) bank. 
Kelemahan ini menunjukkan bahwa pihak bank penyelenggara kartu kredit jarang melangsir sebuah isu-isu lokal dikaitkan dengan karakteristik unik konsumen dalam konteks lokal terhadap perilaku konsumen yang ada. Tidak menggunakan sarana komunikasi pemasaran yang intim dengan keandalan pada kedekatan secara keintiman, yakni; humas (public relations) menunjukkan bahwa bank-bank penyelenggara kartu kredit tidak menganggap penting penguasaan pada hubungan langsung antar pelanggan yang dibalut dengan konsep keintiman yang ada. Komunikasi pemasaran yang diadakan oleh bank-bank penyelenggara kartu kredit lebih bersifat searah dan sepihak, tidak dua arah (dyaadic). Komunikasi model Top Down (Pace, 2003) akan memberikan pemaknaan, bahwa ada pemaksaan terhadap konsep kartu kredit dalam pemahaman penggunaan dari sisi bank-bank penyelenggara kartu kredit. Pelanggan tidak diharapkan memiliki konsep sendiri terhadap kartu kredit tersebut. Semua informasi dan konsep kartu kredit berasal dari bank-bank penyelenggara kartu kredit. Sarana komunikasi pemasaran seharusnya adalah semua aspek mulai dari penjualan pribadi (personal selling), periklanan (advertising), sales promotion, sponsortship marketing, publicity dan point of purchase communication. Semua unsur inilah yang dianggap sebagai komunikasi pemasaran (Brannan, 2004).
Diketahui bahwa bank-bank penyelenggara kartu kredit di Indonesia banyak yang tidak mempraktikkan sepenuhnya sarana komunikasi pemasaran yang ada. Kebanyakan bank-bank penyelenggara kartu kredit menggunakan salah satu sarana komunikasi pemasaran dan mengandalkan sarana ini untuk memperkenalkan dan mempromosikan sebuah produk. Anggapan remeh terhadap keandalan dan konsep keunikan yang ada dalam produk komunikasi pemasaran yang dilaksanakan oleh bank-bank penyelenggara kartu kredit menyebabkan tema dan isu-isu hanya mengikuti yang sudah dilakukan oleh bank-bank leader.

Dari penelitian terhadap 5 penyelenggara kartu kredit di Indonesia ditemukan beberapa aspek penting yang dikaitkan dengan perubahan sikap dari cash society ke electronic society. Dari sisi aspek komunikasi pemasaran, diketahui bahwa banyak bank tidak menggunakan secara optimal praktik sosialisasi sesungguhnya. Mereka hanya berpatokan pada sisi periklanan (advertising) yang ada. Dari sini terlihat penggunaan media cetak nasional dan lokal menjadi sangat dominan dalam mempromosikan kartu kredit.

Pemikiran yang ada adalah pelanggan kartu kredit pasti pembaca media cetak karena mereka dianggap adalah kelas-kelas sosial yang menengah ke atas. Direct marketing saat ini tidak hanya digunakan untuk 
mempromosikan produk kartu kredit itu sendiri. Malah sebaliknya menginformasikan kelebihan dan kelemahan kartu, seperti; program potongan harga, hadiah-hadiah dan sayembara yang ada bila digunakan. Dengan demikian dapat diketahui bahwa Direct Marketing digunakan hanya untuk optimalisasi penggunaan kartu kredit yang ada. Dalam praktik komunikasi pemasaran dalam sosialisasi dan promosi kartu kredit juga diketahui bahwa banyak bank tidak mengutamakan program sendiri. Kebanyakan mereka lebih menggunakan program sosialisasi yang sudah pernah dilakukan oleh bank leader. Dengan demikian terkesan bahwa sosialisasi tentang pengubahan sikap dan perilaku electronic society hanyalah menyadur dan meniru dari bank-bank leader di luar negeri.

Tidak ada pengajuan dan pengangkatan isu-isu lokal dikaitkan dengan pemahaman terhadap aspek budaya menyebabkan pengubahan sikap tersebut terkesan kaku dan sangat berbau peradaban luar negeri. Hal ini merupakan salah satu aspek minimnya pengenalan aspek budaya dalam sosialisasi dan promosi kartu kredit. Di samping itu, tidak adanya kontrol dan evaluasi kerja terhadap sosialisasi dan promosi kartu kredit dalam bentuk riset yang berkesinambungan menyebabkan jalannya promosi dan sosialisasi kartu kredit seperti tanpa adanya panduan yang jelas.
Pola seperti ini dianggap sangat menakutkan karena akan menyebabkan kesalahan intepretasi dari masyarakat. Kondisi yang lebih ditakutkan adalah masyarakat semakin muak dan enggan merubah sikap dari cash society menjadi electronic society. Konsep pengenalan promosi kartu kredit dalam upaya pengubahan masyarakat dari cash society menjadi electronic society dilakukan melalui praktik komunikasi pemasaran yang masih mengikuti (mengekor) dan menyadur dari isu-isu pilihan yang digunakan oleh bankbank swasta asing internasional.

Kendala-Kendala yang muncul dalam implementasi komunikasi pemasaran dalam mengubah sikap masyarakat dari cash society menjadi electronic society adalah beranekaragam. Pertama sulitnya mensosialisasikan produk kartu kredit karena pengetahuan masyarakat di Indonesia yang masih minim terhadap digitalisasi dan internet banking. Di samping itu juga penyusunan komunikasi pemasaran menjadi sulit karena banyak kompetitor baru yang muncul dalam bisnis kartu kredit ini. Kehadiran kompetitor baik dari dalam negeri maupun luar negeri menyebabkan perlu hati-hati dalam pemilihan tagline bank yang saat ini begitu kurang dipahami oleh bank. Produk kartu kredit begitu lekat dengan brand produk luar negeri. Kendala kesulitan melepaskan brand yang ada adalah masalah yang rumit dari promosi produk kartu kredit yang ada. 
Tabel 1 - Pemetaan Strategi Komunikasi Pemasaran Industri Kartu Kredit di Indonesia

\begin{tabular}{|c|c|c|c|c|c|c|}
\hline No & DIMENSI & MANDIRI & HSBC & BCA & CITIBANK & BNI \\
\hline \multirow[t]{4}{*}{1.} & Pilihan strategi & & & & & \\
\hline & $\begin{array}{l}\text { a. Advertising - } \\
\text { Iklan }\end{array}$ & $\begin{array}{l}\text { - Media cetak } \\
\text { dan below the } \\
\text { line } \\
\text { - Acara TV } \\
\text { Program }\end{array}$ & $\begin{array}{l}\text { - Media cetak } \\
\text { nasional }\end{array}$ & $\begin{array}{l}\text { - Acara } \\
\text { program TV } \\
\text { besar- } \\
\text { besaran dan } \\
\text { media cetak } \\
\end{array}$ & $\begin{array}{l}\text { - Media cetak } \\
\text { nasional dan } \\
\text { majalah } \\
\text { ekslusif }\end{array}$ & $\begin{array}{l}\text { Media cetak } \\
\text { dan majalah } \\
\text { di } 15 \text { kota }\end{array}$ \\
\hline & $\begin{array}{l}\text { b. Direct } \\
\text { Marketing }\end{array}$ & - & - & $\begin{array}{l}\text { - Bukan } \\
\text { kartunya tapi } \\
\text { layanan yang } \\
\text { diberikan }\end{array}$ & - & $\begin{array}{l}\text { Kartu kredit } \\
\text { dan PR tidak } \\
\text { berperan }\end{array}$ \\
\hline & c. Below the line & $\begin{array}{l}\text { Pameran- } \\
\text { pameran dan } \\
\text { louncing- } \\
\text { louncing } \\
\end{array}$ & - & - & - & $\begin{array}{l}\text { - Ikut kegiatan } \\
\text { masyarakat, } \\
\text { sosialisasi } \\
\text { dan langsung }\end{array}$ \\
\hline 2. & Taktik bank & $\begin{array}{l}\text { - Meneruskan } \\
\text { taktik leader } \\
\text { bank }\end{array}$ & $\begin{array}{l}\text { - Mengincar } \\
\text { pengusaha } \\
\text { kecil dan } \\
\text { menengah } \\
\text { peranakan } \\
\text { (Tionghoa) }\end{array}$ & $\begin{array}{l}\text { Awareness } \\
\text { spending } \\
\text { melalui } \\
\text { above the } \\
\text { line }\end{array}$ & $\begin{array}{l}\text { - Memperkuat } \\
\text { layanan } e^{-} \\
\text {banking }\end{array}$ & $\begin{array}{l}\text { - Menerapkan } \\
\text { konsep "city } \\
\text { bank" dan } \\
\text { meneruskan } \\
\text { sosialisasi } \\
\text { program } \\
\text { bank leader }\end{array}$ \\
\hline 3. & Tagline & $\begin{array}{l}\text { Untuk semua } \\
\text { dunia anda }\end{array}$ & $\begin{array}{l}\text { the World's } \\
\text { local bank }\end{array}$ & $\begin{array}{l}\text { a Smarter } \\
\text { way to pay }\end{array}$ & $\begin{array}{l}\text { City never } \\
\text { sleep: } 24 \text { jam } \\
\text { service untuk } \\
\text { nasabah dan } \\
\text { world } \\
\text { privileges }\end{array}$ & $\begin{array}{l}\text { - Memberi } \\
\text { makna pada } \\
\text { tiap transaksi }\end{array}$ \\
\hline 4. & Riset & - & $\begin{array}{l}\text { - Dilakukan } \\
\text { oleh bank } \\
\text { dengan } \\
\text { brand } \\
\text { guidance } \\
\end{array}$ & - & $\begin{array}{l}\text { - Dilakukan } \\
\text { oleh } \\
\text { Departemen } \\
\text { tertentu di } \\
\text { bank } \\
\end{array}$ & - \\
\hline 5. & $\begin{array}{l}\text { Kendala- } \\
\text { Kendala }\end{array}$ & $\begin{array}{l}\text { - Sulit } \\
\text { sosialisasi } \\
\text { kartu kredit } \\
\text { dan } \\
\text { mendewasa- } \\
\text { kan } \\
\text { pelanggan }\end{array}$ & $\begin{array}{l}\text { - Sulit } \\
\text { mengubah } \\
\text { brand bank } \\
\text { yang sudah } \\
\text { melekat }\end{array}$ & $\begin{array}{l}\text { - } \text { Banyak } \\
\text { kompetitor } \\
\text { baru }\end{array}$ & $\begin{array}{l}\text { - Program bank } \\
\text { induk tidak } \\
\text { sesuai } \\
\text { keadaan } \\
\text { - Sistem } \\
\text { pelaporan } \\
\text { akan } \\
\text { memakan } \\
\text { waktu yang } \\
\text { lama. }\end{array}$ & $\begin{array}{l}\text { - Sulit berubah } \\
\text { dari satu } \\
\text { pasar ke } \\
\text { pasar yang } \\
\text { lain (pindah } \\
\text { kelas } \\
\text { pelanggan) }\end{array}$ \\
\hline
\end{tabular}

\section{KESIMPULAN DAN SARAN}

\section{Kesimpulan}

Praktik promosi melalui komunikasi pemasaran yang paling kentara terlihat digunakan dalam implementasi kartu kredit adalah sarana iklan. Sebaran iklan tergantung kepada pilihan targeting dalam komunikasi pemasaran. Diketahui bahwa bank Mandiri 
lebih menggunakan iklan dan program acara televisi, media massa cetak dan model below the line. Bank HSBC dalam iklan lebih menggunakan pemasangan iklan pada media cetak nasional. Bank BCA lebih menggunakan iklan dengan menyewa pada televisi dalam bentuk acara televisi. Citibank lebih memilih memasangan iklan di media cetak dan majalah ekslusif, Bank BNI lebih memilih untuk memasang iklan pada media cetak nasional dan lokal di Indonesia.

Sarana penyadaran terhadap tren kehidupan electronic society dapat dilakukan melalui implementasi kerja komunikasi pemasaran yang ada. Pemahaman yang muncul dalam komunikasi pemasaran pada pihak bank sayangnya masih terpengaruh dengan pandangan sempit mencari keuntungan (profit) yang ada. Bank banyak yang berlomba-lomba mencapai brand terhadap electronic society. Oleh sebab itu penyadaran terhadap electronic society tersamarkan dengan iklan produk kartu kredit dan layanan yang mendunia. Padahal seharusnya, komunikasi pemaaran yang dilakukan pihak bank harus bersifatnya mendidik dan memberikan pencerahan dalam konteks komunikasi dan informasi kepada masyarakat.

Komunikasi pemasaran adalah tanggungjawab bagian pemasaran (marketing) semua harus serba mahal, gemerlap dan berlebihan karena mempromosikan produk yang akan menghasilkan keuntungan bagi bank. Pandangan kuno terhadap komunikasi pemasaran masih dipegang oleh para bank penyelenggara kartu kredit di Indonesia. Dengan demikian terkadang komunikasi pemasaran yang dilakukan oleh bank lebih menyangkut faktor pemasaran produk daripada penyadaran dan pendidikan kepada nasabah dan pelanggan.

Komunikasi pemasaran terkadang dianggap sesuatu yang remeh, tanpa perlu perencanaan khusus dan adapatasi dengan lingkungan hidup tempat dilakukan . Konteks budaya (culture) kerap menjadi kendala dalam sosialiasi dan pengenalan pada kehidupan electronic society melalui penawaran produk kartu kredit. Banyak bank yang tidak memahami ini dalam upaya menyadarkan dan memberikan informasi yang tepat kepada masyarakat. Komunikasi pemasaran pada bank-bank penyelenggara kartu kredit di Indonesia terkesan dipaksakan dalam keperluan menciptakan brand produk bank yang unggul antara satu dengan yang lain.

Keberhasilan komunikasi pemasaran sangat tergantung pada perencanaan yang jelas dan ketat. Unsur yang kerap mendasari kerja dari komunikasi pemasaran meliputi; segmentasi, targeting dan positioning perusahaan. Memahami siapa segmentasi dalam komunikasi pemasaran akan menunjukkan kepada siapa komunikasi pemasaran ditujukan untuk keperluan apa? Targeting akan menunjukkan siapa yang 
hendak dituju dan fokus pada kelompok tertentu yang menjadi tujuan dalam komunikasi pemasaran. Faktor terakhir adalah positioning yang menjelaskan pada posisi mana yang memberikan komunikasi pemasaran kepada yang dituju.

\section{Saran}

\section{Prediksi Kondisi Komunikasi Pemasaran} Electronic Society Pada Industri Kartu Kredit

Komunikasi pemasaran dalam perubahan electronic society diyakini akan marak era memasuki AFTA pasar bebas, dimana tidak ada batasan lagi terhadap batas teritorial negara. Semua pelaku bisnis bisa masuk ke negara mana saja, tanpa terkecuali dan pembatasan dari negara. Pasar bisnis kartu kredit di Indonesia menjadi incaran bagi pelaku bisnis termasuk perbankan. Sudah dapat diprediksikan pasar kartu kredit di Indonesia juga akan dimasuki oleh pemainpemain perbankan asing dengan kekuatan modal keuangan dan infrastruktur yang dimiliki lebih besar dan kuat. Tentu saja dalam industri bisnis perbankan pelaku dari luar negeri akan lebih kuat dan berdaya (powerful) daripada pelaku industri bisnis lokal.

Penguasaan isu-isu dan dominasi jargon-jargon asing yang menguasai komunikasi pemasaran perbankan di Indonesia saat ini, semakin memungkinkan begitu mudahnya pasar asing masuk ke Indonesia.
Dalam artian bahwa perbankan Indonesia saat ini 'seperti sedang menari dalam genderang orang lain'. Nilai keuntungan (profitabel) yang besar menjadi dasar perhitungan dalam melakukan pelangsiran isi pesan komunikasi pemasaran. Pelaku industri perbankan di Indonesia tidak mau repot untuk harus melakukan terobosan dan peletakan konsep yang sesungguhnya yang unik dan khusus dari warna kelokalan yang ada. Lambat laun pasar kartu kredit dalam negeri lebih akrab dengan bauran komunikasi pemasaran yang dilakukan pihak asing, daripada bank dalam negeri. Ketika perbankan dalam negeri mengajukan isu kelokalan unik dari dalam negeri sudah tidak digubris, karena isu-isu tersebut juga sudah dikuasai oleh pelaku perbankan asing.

Pergerakan penguasaan isu-isu kelokalan terlihat jelas dengan pergeseran orientasi pasar dan targeting pemasaran perbankan asing saat ini. Layanan-layanan lokal, namun dalam lingkup global akan membanjiri fasilitas kartu kredit. Belum lagi tekanan dan campur tangan negara terhadap perbankan dalam negeri terhadap kartu kredit, seperti; pengenaan pajak dan batas maksimun melakukan transaksi untuk menghindari kejahatan keuangan (money loundring dan penggelapan uang). Belum lagi menyoal suku bunga asing mata uang asing guna menyeimbangkan mata uang dalam negeri.

Dominasi negara yang keliru sebenarnya dalam upaya membatasi gerak 
pelaku bisnis perbankan asing, namun berimbas kepada pelaku perbankan dalam negeri. Tidak tersedianya infrastruktur memadai, seperti jaringan internet, layanan ATM (Anjungan Tunai mandiri), SMS banking dan lain-lain akan menyebabkan matinya gairah untuk mengubah cara hidup ke dalam electronic society. Kondisi ini merupakan peluang bank swasta asing untuk mengakomodasi dalam keperluan perolehan keberpihakan pasar dan kemenangan brand yang dimiliki. Unsur keterbatasan kebebasan informasi dan gagap teknologi merupakan unsur-unsur kendala dalam menjalankan sosialisasi kehidupan yang electronic society.

\section{DAFTAR PUSTAKA}

Ardianto, Natal (2018).”Bertransaksi Online Menggunakan Kartu Kredit di Indonesia Sangatlah Aman!” (tersedia di

https://id.techinasia.com/talk/bertransa ksi-online-menggunakan-kartu-kreditindonesia-sangatlah-aman [diakses 30/1/2018:13.45]).

Assael, David A (2001). Consumer Behaviour and Marketing Action. Singapore: Thomson Learning.

(2004). Marketing Insight from A to Z. Jakarta: Gelora Aksara Pratama.

Belch, George and Michael Belch, (2004). Advertising and Promotion: An Integrated Marketing Communication Perspectives. New Jersey: New York.

BKPM (2008). the Report Indonesia 2008. Jakarta : Oxford Business Group.
Brannan, Tom (2004). Integrated Marketing Communication: A Practical Guide to Integrated Marketing Communication. London: Sage Publication.

Drucker, P. F(1999). the Practice of Management, London : Heinemann

Drucker, P.F (1992) Managing for the Future: The 1990's and Beyond. Truman: Penguin Group.

Duncan, Tom (2002). IMC: Using Advertising and Promotion to Build Brand. New York: McGraw Hill Publication.

Jain, Subhash (1990). Marketing Planning and Strategy. Cincinnati: South Western Publishing.

Jefkins, Frank (1994). Advertising. London: Pitman Publishing.

Kennedy, John (2006). Marketing Communication: Teknik dan Strategi. Jakarta: Buana Ilmu Populer.

Kotler, Philip (2000). Principle of Marketing. Ninth Edition. New Jersey : Prentice Hall.

Kotler, Philip and Kevin Lane Keller (2009). Marketing Management.13th. edition. London : Prentice Hall

Kriyantono (2006), Riset Komunikasi. Jakarta : PT Buana Citra Pustaka.

Lwin, May and Jim Aitchison (2005). Clueless in Marketing Communications (terjemahan). Jakarta : Buana Ilmu Populer.

Moehajir (1994), Penelitian Kualitatif. Jakarta : Ghalia Pustaka. 
Moleong, Lexy. J (2004). Metodologi Penelitian Kulitatif. Bandung : PT. Remaja Rosdakarya.

Mooij, Marieke (2005). Global Marketing and Advertising: Understanding Cultural Paradoxes. London: Sage Publication.

Mulyana, Deddy dan Jalaluddin Rakhmat (eds) (2003). Komunikasi Antar Budaya: Panduan Berkomunikasi dengan Orang-Orang Berbeda Budaya. Bandung: Rosdakarya.

Narbuko, Cholid \& M. Abu Achmadi (2001). Metodologi Penelitian, Jakarta : PT. Bumi Aksara.

Pacey, Arnold. (1983). the Culture of technology. Cambridge: MIT Press.

Pattilima, Hamid (2005). Metodologi Penelitian Kualitatif. Bandung : Alfabeta.

"Pengguna Kartu Kredit di Indonesia Masih Minim," (tersedia di http://www.pikiran-

rakyat.com/ekonomi/2017/02/07/pengg una-kartu-kredit-di-indonesia-masih-

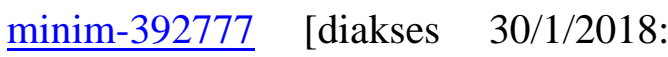
14.00]).

Prisgunanto, Ilham (2006). Komunikasi pemasaran, Strategi dan Taktik: disertai analisis SOSTAC dan STOPSIT. Jakarta: Ghalia Indonesia.

Schultz, Don. E dan Philip J Kitchen (2000) Communicating Globally, an Integrated Marketing Approach. New Jersey: Prentice Hall.

Sirgy, Joseph (1998). Integrated Marketing Communication : a System Approach. New Jersey: Prentice Hall.
Smith, Paul (1997). Strategic Marketing Communication. Australia: Prentice Hall.

Smith, PR. (2004). Marketing Communications: an integrated appoarch. London : Kogan Smith.

Soemanagara, Rd (2006). Strategic Marketing Communication. Jakarta:Alfabeta.

Straubhaar and La Rose (2004). Media now: understanding media culture, and technology. $\quad 4^{\text {th }}$. ed. Belmont:Wadsworth.

Sulaksana, Uyung (2003). Integrated Marketing Communications: Teks dan Kasus. Yogyakarta: Pustaka Pelajar.

Sutisna. (2001). Perilaku Konsumen dan Komunikasi Pemasaran. Bandung:Rosdakarya.

Yin, Robert K (2004). Studi Kasus : Desain dan Metode, Jakarta : Raja Grafindo Persada. 